\title{
Sistem Monitoring Tekanan Darah Berbasis Wireless
}

\author{
Blood Pressure Monitoring System Based on Wireless
}

\author{
Alamsyah $^{1}$, Mery Subito ${ }^{2}$, Ardi Amir ${ }^{3}$ \\ 1,2,3 Teknik Elektro, Fakultas Teknik, Universitas Tadulako \\ E-mail: ${ }^{1}$ alamsyah.zakaria@ untad.ac.id, ${ }^{2}$ subitomery@yahoo.com, ${ }^{3}$ ardi.amir@yahoo.com
}

\begin{abstract}
Abstrak
Teknologi jaringan nirkabel saat ini menjadi pesat dan berkembang khususnya di bidang monitoring kesehatan seperti monitoring tekanan darah. Pemeriksaan tekanan darah sangat penting dilakukan untuk mengetahui kondisi sistem peredarah darah pasien. Umumnya petugas kesehatan menggunakan tensimeter analog atau digital dalam melakukan pemeriksaan tekanan darah. Namun, penggunaan alat ini masih memiliki kelemahan khususnya dalam pengambilan data, dimana peralatan yang digunakan masih berbasis kabel belum menggunakan modul wireless. Kondisi tersebut tentunya membutuhkan waktu yang cukup lama dalam melakukan proses diagnosa terkait kondisi kesehatan pasien. Untuk meningkatkan pelayanan kesehatan dengan jumlah tenaga medis yang terbatas maka peneliti membuat perangkat monitoring tekanan darah berbasis wireless dengan menggunakan modul raspberry $p$ i. Penelitian ini bertujuan untuk membantu tenaga medis dalam memonitor tekanan darah pasien, mempermudah proses pengambilan data secara real time, dan mengurangi terjadinya kesalahan diagnosa penyakit pasien. Rancangan yang dibuat dapat diterapkan pada rumah sakit, puskesmas, dan panti jompo. Hasil pengujian menunjukkan bahwa rancangan yang diusulkan berkerja dengan normal dengan tingkat akurasi mencapai 97,53\%.
\end{abstract}

Kata kunci: monitoring kesehatan, tekanan darah, raspberry $p i$

\begin{abstract}
Wireless network technology is currently becoming rapid and developing, especially in the field of health monitoring, such as blood pressure monitoring. Blood pressure checks are essential to know the condition of the patient's bloodstream system. Generally, health workers use analog or digital tensimeters to check blood pressure. However, the use of this tool still has weaknesses, especially in data retrieval, where the equipment used is still cable-based not using wireless modules. This condition certainly requires quite a long time in conducting the diagnosis process related to the patient's health condition. To improve health services with a limited number of medical personnel, the researcher made a wireless-based blood pressure monitoring device using the raspberry pi module. This study aims to assist medical personnel in monitoring patient's blood pressure, making it easy the process of retrieving data in real-time and reducing the occurrence of misdiagnoses of patients' illnesses. The design that made can apply in hospitals, health centers, and nursing homes. The test results show that the proposed plan works typically with an accuracy rate of $97.53 \%$.
\end{abstract}

Keywords: health monitoring, blood pressure, raspberry pi

\section{PENDAHULUAN}

Perkembangan teknologi jaringan nirkabel saat ini semakin maju dengan pesat dan positif [1] khususnya di bidang kesehatan seperti monitoring vital sign. Salah satu parameter vital sign yang sangat penting dalam sistem sirkulasi darah pada tubuh manusia adalah detak jantung $[2,3]$ dan tekanan darah. Pemeriksaan tekanan darah diperlukan untuk mengetahui kondisi sistem peredarah darah apakah meningkat (hipertensi) atau menurun (hipotensi) [4]. 
Faktor tekanan darah sangat mempengaruhi hemositas di dalam tubuh [5] dan dapat menimbulkan berbagai penyakit [6] seperti serangan jantung [7]. Pemeriksaan tekanan darah perlu dilakukan secara berkala untuk mengetahui kondisi dini penyakit dan menjadi tolak ukur bagi pasien dalam mencari bantuan medis. Pemeriksaan vital sign seperti tekanan darah dapat dilakukan dengan menggunakan tensimeter analog atau digital.

Pemeriksaan tekanan darah menggunakan tensimeter oleh tenaga medis sudah cukup membantu pasien dalam mendiagnosa penyakit. Namun, peralatan ini masih memiliki kelemahan dalam meningkatkan pelayanan kesehatan karena petugas medis harus melakukan pemeriksaan pasien di setiap kamar dan alat ini belum mampu mengirim data pasien ke semua uni secara real time. Keterbatasan jumlah tenaga medis dalam melayani pasien tentunya memerlukan waktu yang cukup lama, menambah beban kerja petugas medis [8], dan biaya administrasi menjadi meningkat khususnya dalam menyediakan infrastruktur monitoring di setiap kamar pasien [9].

Penelitian terkait dengan tekanan darah yang telah diusulkan diantaranya sistem pengukuran tekanan darah menggunakan Arduino [10]. Hasil penelitiannya menunjukkan bahwa rancangan yang diusulkan bekerja dengan baik dengan tingkat akurasi mencapai 99,47\% - 99,82\% [11], data dapat dikirim melalui Bluetooth [12], dan penggunaan modul ESP8266 mampu mentransfer data ke komputer server sebesar 28-30 detik [13]. Namun, peneliti belum mengembangkan ke perangkat berbasis raspberry pi dan jangkauan pengiriman data masih terbatas.

Analisis kinerja protokol routing AODV, DSR, DSDV, dan OLSR pada mobile adhoc network (MANET) berdasarkan quality of service (QoS). Hasil penelitian menunjukkan bahwa protokol OLSR sangat mendukung untuk diterapkan pada jumlah pasien yang lebih padat [14]. Protokol AODV memiliki delay yang lebih baik dibanding DSR, DSDV, dan OLSR [15]. Namun, penelitian yang dilakukan masih sebatas simulasi jaringan menggunakan network simulator (NS3) belum dikembangkan ke perangkat monitoring kesehatan.

Berdasarkan permasalahan yang telah dikemukanan di atas, maka peneliti mengusulkan rancangan sistem monitoring tekanan darah berbasis wireless menggunakan perangkat modul raspberry pi. Tujuan rancangan yang diusulkan ini adalah mengurangi beban kerja petugas kesehatan melalui monitoring tekanan darah pasien secara real time, meningkatkan pelayanan kesehatan secara professional [16], dan mengurangi kesalahan diagnosa penyakit [17].

\section{METODE PENELITIAN}

Penelitian ini bertujuan untuk merancang sistem pemantauan tekanan darah berbasis wireless dengan menggunakan modul raspberry pi. Penelitian ini meliputi beberapa tahapan diantaranya studi literatur, perancangan perangkat keras dan lunak, pengujian, pengambilan data, dan analisis.

\subsection{Studi Literatur}

Studi literatur bertujuan untuk mengumpulkan bahan dalam mendukung penelitian yang terkait dengan tekanan darah dan metode yang digunakan dalam merancang modul tekanan darah. Bahan dan informasi yang dikumpulkan melalui wawancara dengan pihak yang terkait langsung dengan penelitian medis khususnya tekanan darah, referensi penelitian dalam bentuk jurnal atau prosiding baik nasional maupun internasional, dan buku teks. Gambar 1 menunjukkan tahapan penelitian yang dilakukan. 


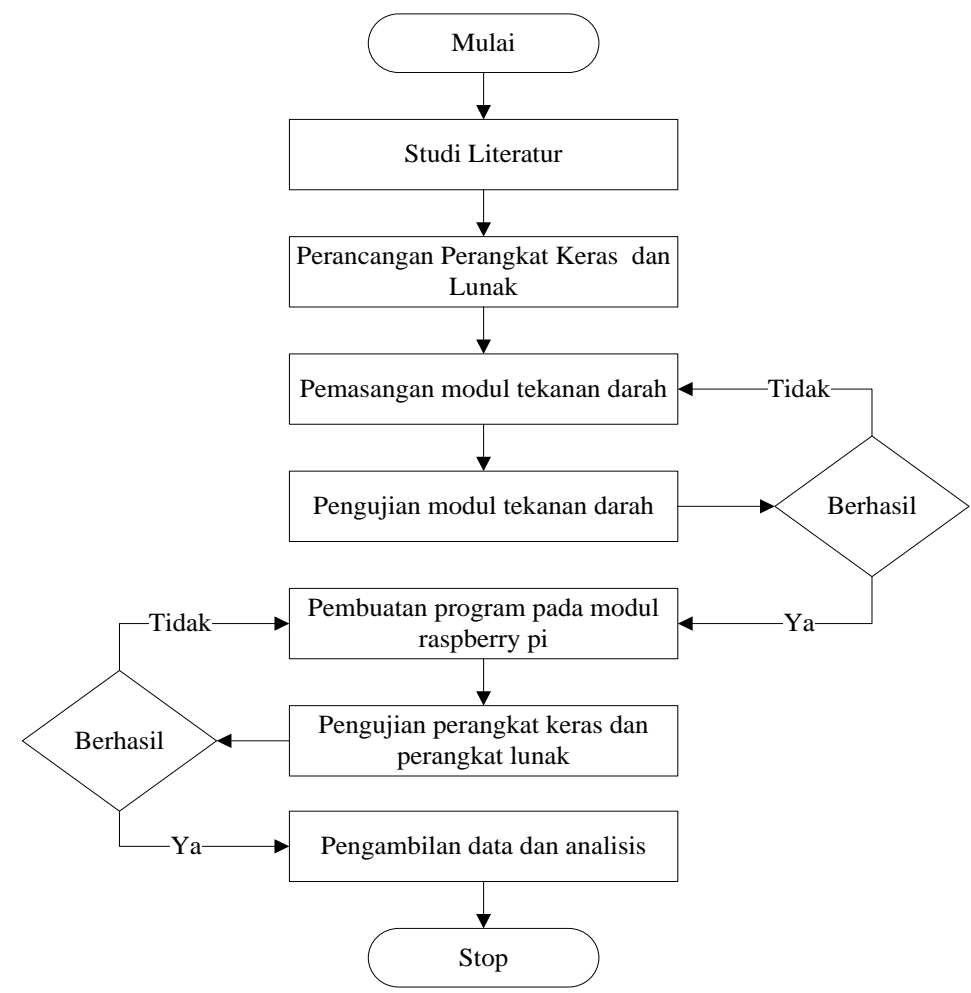

Gambar 1 Proses tahapan penelitian

\subsection{Perancangan Sistem}

Perancangan sistem meliputi perancangan perangkat keras (hardware) dan perangkat lunak (software). Pada gambar 2 menunjukkan rancangan sistem monitoring tekanan darah berbasis wireless menggunakan modul raspberry pi.

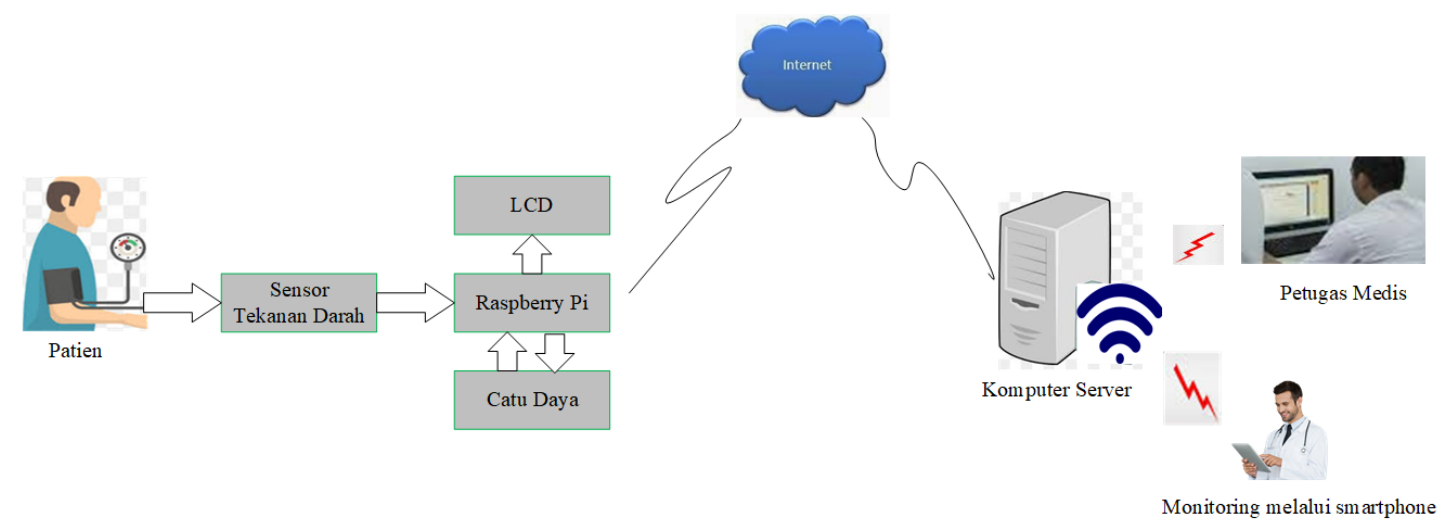

Gambar 2 Rancangan sistem penelitian

\subsubsection{Perancangan Perangkat Keras}

Perancangan perangkat keras terdiri dari sensor tekanan darah, modul raspberry pi, catu daya, dan LCD. Sistem monitoring tekanan darah menggunakan sensor tipe MPX5050GP. Sensor ini berfungsi untuk mengukur tekanan udara menjadi sinyal listrik dengan menggunakan teknologi piezoresistive yang dibuat dari monolithic silicon. Sensor MPX5050GP merupakan sensor yang tergolong akurat dengan tingkat akurasi $50 \mathrm{kPa}$ dengan tekanan $0-300 \mathrm{mmHg}$ dan bekerja pada tegangan 4,75 - 5,25 volt. Gambar 3 menunjukkan diagram blok sistem monitoring tekanan darah menggunakan raspberry pi. 

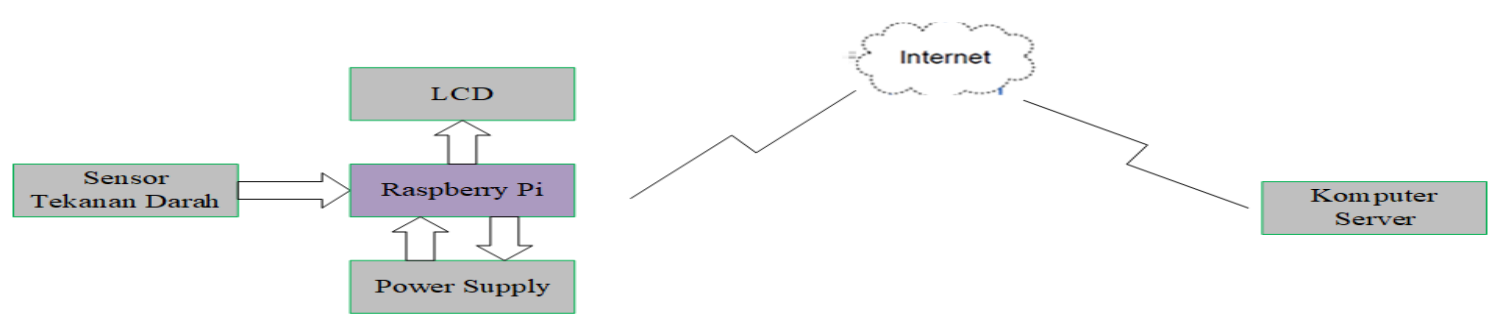

Gambar 3 Rancangan perangkat keras

Prinsip kerja MPX5050GP adalah mengambil data tekanan darah dengan cara udara dipompa pada handcuff yang terlilit di lengan hingga mencapai tekanan tertentu. Sensor ini telah terhubung dengan kondisi sinyal dan op-amp internal, sehingga output yang dihasilkan dalam bentuk konversi analog ke digital. Selanjutnya modul raspberry pi akan menerima sinyal tekanan handcuff sebagai hasil tekanan sistolik dan distolik dengan satuan mmHg.

Tekanan darah merupakan hasil dari aktivitas pemompaan jantung yang berlangsung secara kontraksi dan relaksasi. Nilai dari tekanan darah dapat diukur menggunakan spygmomanometer. Pemeriksaan tekanan darah sangat penting mengingat bahwa berbagai penyakit dapat terjadi akibat tekanan darah yang tidak normal. Tekanan darah orang dewasa yang normal berkisar antara $120 \mathrm{mmHg}$ sistole dan $80 \mathrm{mmHg}$ diastole [18]. Pengukuran tekanan darah dilakukan pada lengan. Sensor tekanan darah yang digunakan dalam penelitian ini adalah sensor MPX5050GP. Sensor ini mengambil data tekanan darah dengan cara udara dipompa pada handcuff yang terlilit di lengan hingga mencapai tekanan tertentu dengan satuan mmHg. Pengukuran tekanan darah manusia berdasarkan usia dapat dilihat pada Tabel 1 .

Tabel 1 Tekanan Darah Berdasarkan Usia [19]

\begin{tabular}{|c|c|c|}
\hline Umur & Sistole $\mathbf{~} \mathbf{m m H g})$ & Diastole $\mathbf{~} \mathbf{m m H g})$ \\
\hline Baru lahir & $60-90$ & $20-60$ \\
\hline 1 bulan -1 tahun & $75-100$ & $50-70$ \\
\hline $1-3$ tahun & $80-110$ & $55-80$ \\
\hline $3-6$ tahun & $80-110$ & $50-80$ \\
\hline $6-12$ tahun & $100-110$ & $60-70$ \\
\hline $12-18$ tahun & $110-120$ & $60-65$ \\
\hline $19-69$ tahun & $110-140$ & $60-90$ \\
\hline$>70$ tahun & $120-140$ & $70-90$ \\
\hline
\end{tabular}

\subsubsection{Perancangan Perangkat Lunak}

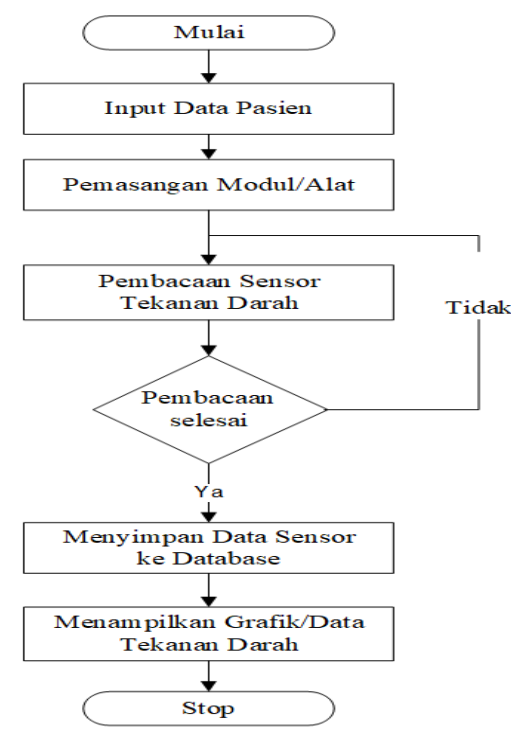

Gambar 4 Diagram alir perancangan perangkat lunak 
Setelah dilakukan perancangan perangkat keras, maka langkah selanjutnya adalah merancang perangkat lunak. Program aplikasi yang digunakan dalam menjalankan komunikasi antara sensor dengan modul raspberry pi adalah Integrated Developtment Enviroenment (IDE). Modul IDE digunakan untuk menampilkan data sensor melalui pembuatan program pada raspberry pi dengan menggunakan bahasa C. Hasil data program dibuat dalam teks editor (sketch) dan disimpan dalam file dengan ekstensi ino. Pembuatan database dan web menggunakan aplikasi MySQL, PHP, dan Dreamweaver.

Gambar 4 menunjukkan diagram alir perangkat lunak yang dimulai dengan melakukan proses input data pasien yang meliputi id-pasien, nama, alamat, usia, jenis kelamin, dan nomor telepon. Setelah proses data input dilakukan maka dilanjutkan ke pemasangan modul sensor tekanan darah ke pergelangan tangan pasien. Selanjutnya sensor akan melakukan deteksi tekanan darah pasien dalam bentuk pembacaan tegangan (analog). Data analog ini akan diproses oleh modul raspberry pi dengan mengkonversi ke dalam bentuk nilai digital dengan satuan $\mathrm{mmHg}$. Jika sensor tidak bisa menampilkan data (error) maka proses pembacaan dilakukan kembali, sebagai contoh jika tidak bisa mencapai tekanan yang diharapkan atau melebihi dari batas ambang tekanan. Namun, jika pembacaan data sensor berhasil, maka data tekanan darah akan ditampilkan pada LCD atau komputer server melalui koneksi internet. Data tekanan darah yang berhasil terdeteksi dan dikonversi ke mmHg akan disimpan ke database. Selanjutnya data tekanan darah yang tersimpan pada database dapat ditampilkan kembali dalam bentuk grafik atau tabel yang sesuai dengan kebutuhan pengelola layanan kesehatan pada sistem monitoring tekanan darah.

\subsection{Pengujian Rancangan Tekanan Darah}

Sebelum melakukan pengambilan data tekanan darah terlebih dahulu dilakukan pengujian rancangan yang diusulkan. Pengujian ini bertujuan untuk memastikan kondisi sensor tekanan darah bekerja dengan normal. Pengujian sensor tekanan darah dipasang di lengan pasien, dimana setiap sampel diuji sebanyak 10 percobaan. Data yang ditampilkan adalah data analog dari sensor tekanan darah yang dikonversi ke digital oleh raspberry pi. Hasil pengujian sensor tekanan darah akan dibandingkan dengan nilai yang dihasilkan oleh tensimeter digital. Tampilan nilai mmHg pada LCD menunjukkan bahwa sensor berfungsi normal. Gambar 5 pengujian sensor MPX5050GP dan tensimeter digital.

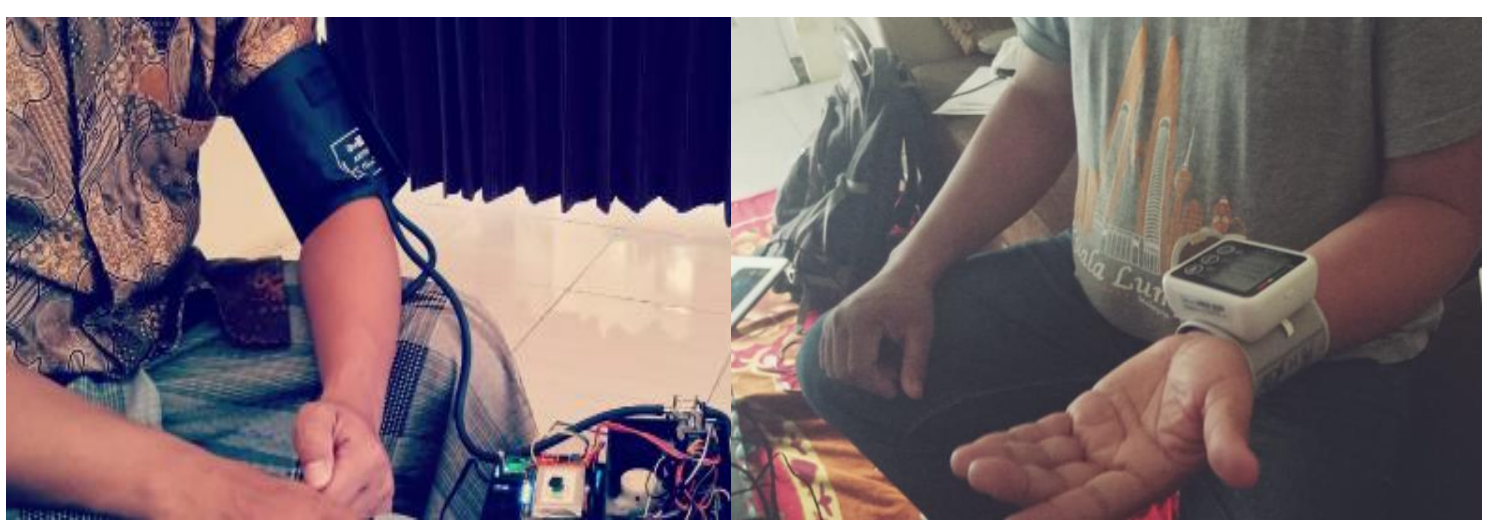

Gambar 5 Pengujian sensor MPX5050GP dan tensimeter digital

\subsection{Pengujian Jangkauan Pengiriman Data}

Pengujian pengiriman data vital sign dilakukan dalam dua kondisi. Pertama, kondisi ruang terbuka tanpa penghalang. Kedua, pada kondisi ruang tertutup dengan penghalang. Pada kondisi ruang terbuka tanpa penghalang maksimal 65 meter dan pada kondisi ruang tertutup dengan penghalang maksimal 12 meter. Gambar 6 menunjukkan pengujian alat berdasarkan jangkauan pengiriman data. 


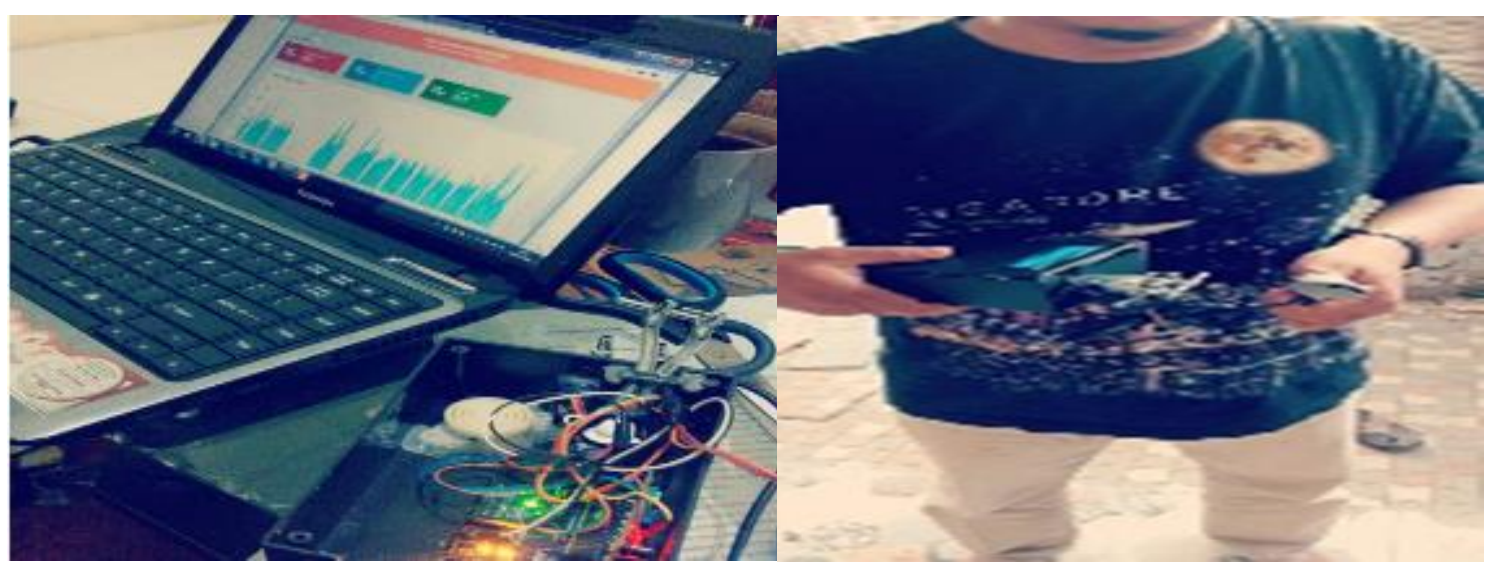

Gambar 6 Pengujian jangkauan transmisi data tekanan darah

\section{HASIL DAN PEMBAHASAN}

\subsection{Pengambilan Data Tekanan Darah}

Tujuan pengukuran tekanan darah adalah untuk mengetahui kondisi kesehatan tekanan darah pasien. Ambang tekanan darah yang dikategorikan sebagai standar untuk orang dewasa adalah 110 - $140 \mathrm{mmHg}$ sistole dan $60-90 \mathrm{mmHg}$ diastole. Hasil pengambilan data diperoleh nilai rata-rata 116 - $127 \mathrm{mmHg}$ (sistole). Kinerja sensor yang dirancang bekerja dengan baik dengan tingkat kesalahan rata-rata 2,47\%. Pengambilan data tekanan darah dapat dilihat pada tabel 2.

Tabel 2 Hasil pengambilan data tekanan darah

\begin{tabular}{|c|c|c|c|c|}
\hline \multirow[t]{2}{*}{ No } & \multirow{2}{*}{$\begin{array}{c}\text { Id_Number } \\
\text { Pasien }\end{array}$} & \multicolumn{2}{|c|}{ Tekanan Darah (mmHg) } & \multirow{2}{*}{$\begin{array}{c}\text { Error } \\
(\%)\end{array}$} \\
\hline & & MPX5050GP & Tensimeter Digital & \\
\hline 1 & 001 & 119 & 120 & 0,83 \\
\hline 2 & 002 & 127 & 127 & 0 \\
\hline 3 & 003 & 125 & 128 & 2,34 \\
\hline 4 & 004 & 120 & 125 & 4 \\
\hline 5 & 005 & 124 & 128 & 3,13 \\
\hline 6 & 006 & 127 & 127 & 0 \\
\hline 7 & 007 & 120 & 125 & 4 \\
\hline 8 & 008 & 120 & 122 & 1,64 \\
\hline 9 & 009 & 116 & 122 & 4,92 \\
\hline 10 & 010 & 125 & 130 & 3,85 \\
\hline \multicolumn{4}{|c|}{ Rata-rata Tingkat Kesalahan } & 2,47 \\
\hline
\end{tabular}

\subsection{Monitoring Tekanan Darah}

Pada menu aplikasi sistem monitoring tekanan darah dilengkapi dengan beberapa fasilitas seperti menu login, input data pasien (id-pasien, nama, umur, jenis kelamin, alamat, dan nomor telepon), data laporan pasien, proses pengambilan data detak jantung, penyimpanan data pasien, dan tampilan nilai tekanan darah, timer, sinyal tekanan darah, dan waktu pengambilan data secara real time.

Proses pengambilan data dilakukan dengan memasukkan data pasien. Setelah data pasien dimasukkan, maka dilanjutkan pemasangan sensor tekanan darah (MPX5050DP) ke lengan pasien. Selanjutnya memasukkan durasi waktu (menu time)untuk proses pengambilan data dan memilih menu proses (menu process) sebagai tanda pengambilan data pasien. Data pasien yang telah diproses akan ditampilkan pada liquid crystal display (LCD) atau layar monitor dengan nilai $\mathrm{mmHg}$ (tekanan darah). Data tekanan darah pasien yang diperoleh dapat disimpan dan ditampilkan kembali dengan memasukkan id-number pasien. Gambar 7 dan 8 menunjukkan pemrosesan tekanan darah. 


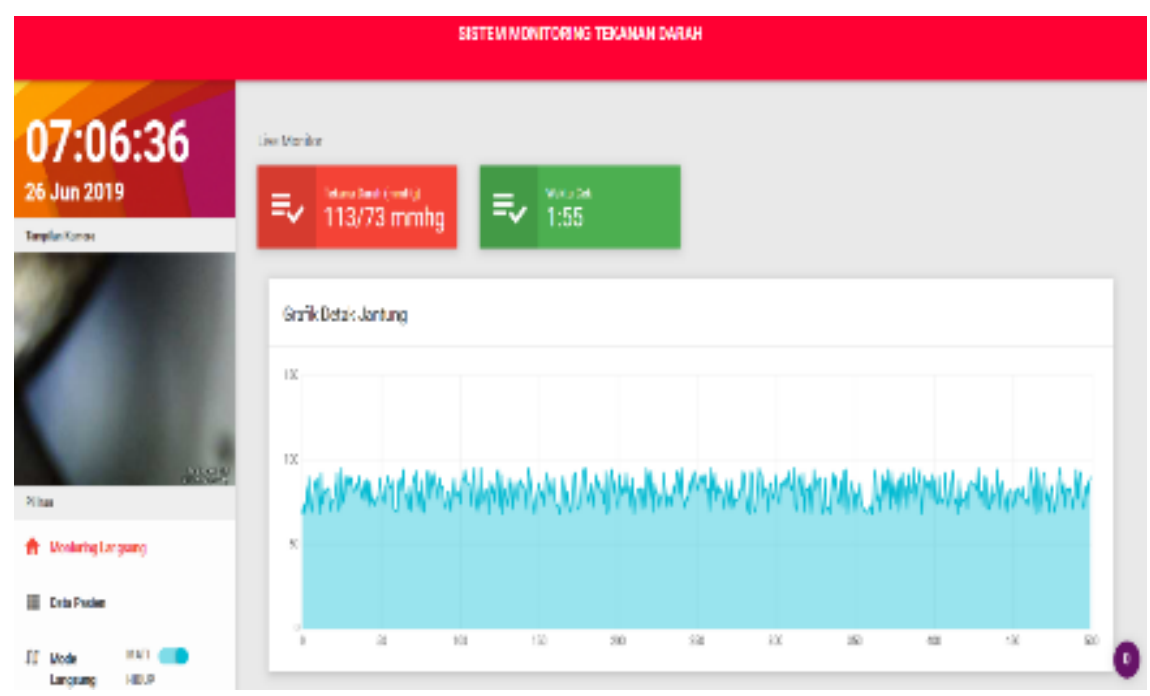

Gambar 7 Informasi data pasien

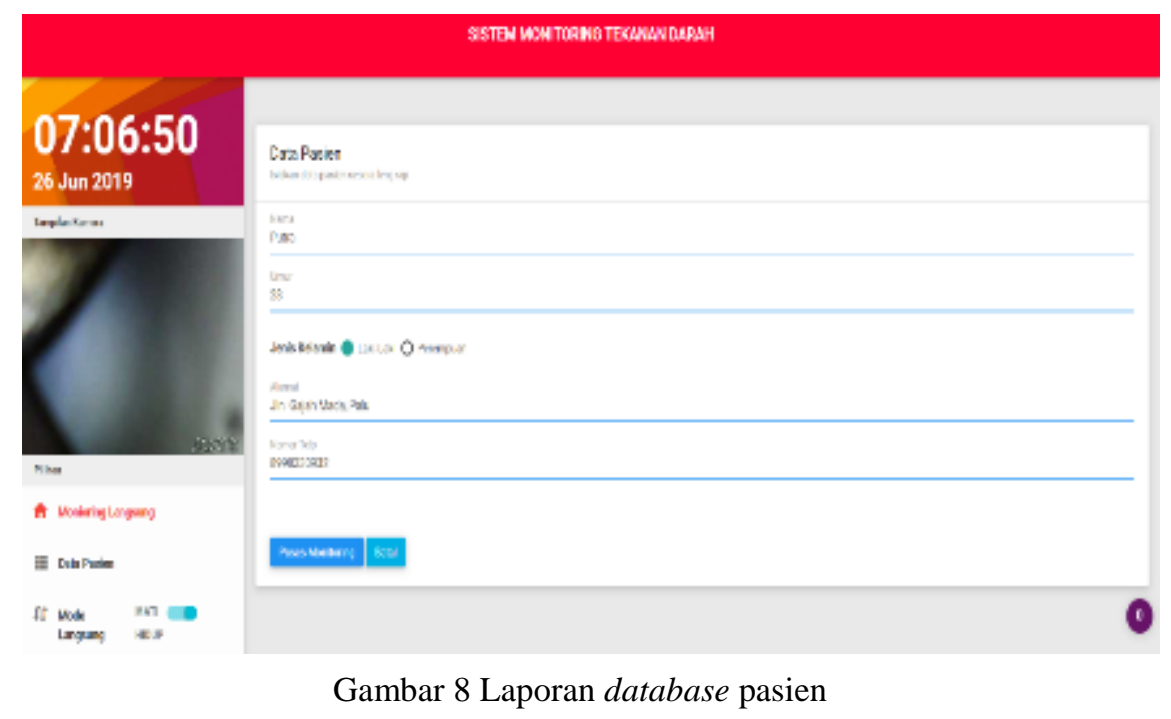

\section{KESIMPULAN DAN SARAN}

Penelitian ini dirancang untuk membantu petugas kesehatan dalam memonitor tekanan darah pasien secara wireless dengan menggunakan modul raspberry pi, mengurangi kesalahan diagnosa penyakit, dan meningkatkan pelayanan kesehatan secara optimal dan efisien. Sistem yang dirancang dapat diaplikasikan di rumah sakit, puskesmas, dan panti jompo. Hasil rancangan sistem monitoring tekanan darah yang diusulkan bekerja dengan baik dengan tingkat kesalahan sebesar 2,47\% dibandingkan dengan menggunakan tensimeter digital.

Penelitian ini diharapkan dapat dilanjutkan dengan menambah beberapa sensor vital sign dan sensor alarm sebagai informasi layanan darurat ke tenaga medis melalui pesan singkat di smartphone. Rancangan yang diusulkan perlu ada penambahan aplikasi program atau metode pengambilan keputusan yang dapat menampilkan informasi terkait kondisi tekanan darah pasien apakah penyakit yang diderita dalam keadaan normal, cukup beresiko, atau sangat beresiko. Rancangan aplikasi sistem keputusan ini diharapkan dapat membantu tenaga medis dalam memutuskan kondisi penyakit yang di derita pasien. 


\section{UCAPAN TERIMA KASIH}

Penulis mengucapkan terima kasih kepada Riset, Teknologi, dan Pendidikan Tinggi Republik Indonesia (RISTEKDIKTI) yang telah memberikan dukungan dalam bentuk pembiayaan Hibah Penelitian Terapan Tahun Anggaran 2019.

\section{DAFTAR PUSTAKA}

[1] Shedge, S., 2010, Remote Patient Monitoring Network Cluster. Proceedings of the 2nd Makassar International Conference on Electrical Engineering and Informatics (MICEEI), Makassar Golden Hotel (MGH) Makassar, South Sulawesi, Indonesia, October 27.

[2] Tan S. Sollu, Alamsyah, Muhammad Bachtiar, dan Adri G. Sooai, 2018, Patients' Heart Monitoring System Based on Wireless Sensor Network. IOP Conf. Series: Materials Science and Engineering, vol 336, hal. 1-10.

[3] T. S. Sollu, Alamsyah, M. Bachtiar, and B. Bontong, 2018, Monitoring System Heartbeat and Body Temperature Using Raspberry Pi, E3S Web of Conferences, volume 73, hal. 1-5.

[4] R.Harini, Prof. B. Rama Murthy, 2017, Development of a Wireless Blood Pressure Monitoring System by Using Smartphone, International Journal of Advanced Research in Electronics and Communication Engineering (IJARECE), vol 6, hal 1383-1386.

[5] Yazid, N. dan A. Harjoko, 2011, Pemantau Tekanan Darah Digital Berbasis Sensor Tekanan MPX2050GP, Skripsi, Jurusan Ilmu Komputer dan Elektronika Fakultas MIPA Universitas Gajah Mada, Yogyakarta.

[6] Rahajeng, E., dan Tuminah, S., 2009. Prevalensi Hipertensi dan Determinannya di Indonesia, Majalah Kedokteran Indonesia, vol 59, hal 580-587.

[7] National Heart Foundation of Australia, Guideline for the diagnosis and management of hypertension in adults. National Heart Foundation of Australia, 2016.

[8] Tan Suryani Sollu, Alamsyah, Muhammad Bachtiar, 2017, Sistem Pemantauan Sinyal Detak Jantung Pasien Menggunakan Protokol Zigbee dan Arduino, Jurnal Techno.COM, vol 16, hal 411-420.

[9] Tan Suryani Sollu, Alamsyah, Muhammad Bachtiar, dan Benyamin Bontong, 2018. Sistem Monitoring Detak Jantung dan Suhu Tubuh Menggunakan Arduino. Jurnal Techno.COM, vol 17, hal 323-332.

[10] S. Poornachandra, V.Nivedha, S. Arun, dan M. Shankar, 2018, Blood Pressure Measurement using Arduino, International Journal for Research in Applied Science and Engineering Technology (IJRASET), vol 6, hal 2469-2472.

[11] Ratnadewi, Mohammad Faizal Ramdhani, Nuning Kurniasih, Lusi Dwi Putri, Parwito, Dahlan Abdullah, Tri Listyorini, Muhammad Ilham Bakhtiar, Ricardo Freedom Nanuru, dan Robbi Rahim, 2018, Automatic Blood Pressure Detector Using Arduino to Measure Blood Pressure in Indonesian People Age 19 - 27 Years Old, 2018, International Journal of Engineering and Technology, 2018, vol 7, hal 115-118.

[12] Sholihudin Dwi Prihatono Tanjung, 2017, Tensimeter Digital Berbasis Arduino Dengan Transfer Data Berbasis Android Melalui Bluetooth, Skripsi, Program Studi Teknik Elektro Fakultas Teknik Universitas Muhammadiyah, Surakarta.

[13] Budi Dwi Satoto, 2017, Monitoring Kesehatan Menggunakan Compiler Arduino dan Modul Wifi-ESP8266 untuk Komunitas Pasien Hipertensi, Seminar Nasional Matematika dan Aplikasinya, Universitas Airlangga, Surbaya, Indonesia, 21 Oktober.

[14] Ravi Tiwari, Sonam Shrivastava, dan Susmita Das, 2015, Performance Analysis of Patient Monitoring System Under Different Routing Algorithm, IEEE International Conference for Convergence for Technology, Pune, India, April 6.

[15] Alamsyah, Mauridhi H. Purnomo, I Ketut E. Purnama, dan Eko Setijadi, 2016. Performance of The Routing Protocols AODV, DSDV and OLSR in Health Monitoring 
Using NS3, IEEE International Seminar on Intelligent Technology and Its Application (ISITIA), The Santosa Villas and Resort Lombok, Mataram, Indonesia, July 28.

[16] Rhonda Chetney, 2003, Home Care Technology and Telehealth, Wolters Kluwer Health, USA, vol 21, hal. 645-646.

[17] Ruri Hartika Zain, Silvia Afrilla, Rancang Bangun Alat Pengukuran Tekanan Darah dan Suhu Tubuh Berbasis Mikrokontroller ATmega 8535 Didukung Bahasa Pemograman C dan Delph, 2012, Poli Rekayasa Volume 7, Nomor 2, hal. 64-75.

[18] N. H. Lung and B. I. (NHLBI), "Description of high blood pressure." https://www:nhlbi:nih:gov/health/health-topics/topics/hbp, September 2015.

[19] Clinicalgate, "The physical examination and its basis in physiology.”https://clinicalgate:com/the-physicalexamination-and-its-basis-in-physiology. 